\title{
ルート割れと最高かたさ*
}

鈴 木 替 義**

\author{
Root Cracking and Maximum Hardness in High-Strength Steel Welds*
}

by Haruyoshi Suzuki**

\begin{abstract}
Effects of maximum hardness in the HAZ on root crack initiation in the JIS-y (oblique-Y groove) cracking test are discussed. The values of critical hydrogen concentration $\mathrm{Hc}$ at the location of root crack initiation at $100^{\circ} \mathrm{C}$ on the way of cooling, were calculated, assuming uniform diffusion of hydrogen through weld zone. The value of $\log \mathrm{Hc}$ decreased linearly with an increase of $H_{\max }$, depending on the intensity of restraint. The correlation between $\log \mathrm{Hc}$ and $\mathrm{Hmax}$ was found to be far poorer than that between $\log \mathrm{Hc}$ and $P \mathrm{~cm}$, Ito and Bessyo carbon equivalent, which is adequate for low carbon content steels. An analysis by the cracking parameter $\boldsymbol{P}_{\boldsymbol{H A}}$, proposed by the author considering local accumulation of hydrogen at the site of crack initiation, revealed that $\log H_{c}$ vs. $H_{\max }$ relation is severely affected by the $\mathrm{C} \%$ of test steels, thus a wide scatter in Hc values. For the same value of $H_{\max }$, a lower carbon content is more favourable against root cracking. The estimation agrees well with the JIS-y test result. The critical values of $H_{\max }$ for crack-free welding without preheating, have been $P_{Z A^{-}}$-estimated depending on $H_{D}$ values. As an application, the $P_{\boldsymbol{H A}}$-estimated critical values of $H_{\max }$ agree satisfactorily with the Harasawa-Hart's observed values in the H-type self-restrained root cracking tests.
\end{abstract}

1. 緒言

高張力鎆の溶接热影留部 (HAZ) の最高功ささ $H_{\max }$ が大きいほど水素による HAZ の低温割れが発生しやす いことは䍃知の事実である。たとえば HT 50 鋼では350 Hv 10 少普通の低水絜系溶接捧化よる割机発生の限界か たさとして欧州 (IIW) では常識となっている。また最 近の海洋構造物用鋼材 (HT 50 級)では, 割れ防止の目 的で安全を考えて

$$
H_{\max } \leqq 325(\mathrm{Hv} 5 \sim 10)
$$

が確保できるように，鋼材選定と溶接施工条件に留意す る要求が普通になっている.

\section{2. $\boldsymbol{H}_{\max }$ の推定式}

低温割れの発生と非発生の限界 $H_{\max }$ は，溶着金属水 觉量, 拘束度, HAZ の化学成分とミク口組織に影響さ れる.また $H_{\max }$ と低温割れの発生条件とは相関が不良 と言われているが，欧米における $H_{\max }$ の重視の事実に かんがみ，限界 $H_{\max }$ の定量的検討を, JIS-y 試験デー タを用いて試みた結果を報告する。

著者の新しい割れ指数 $P_{H A}$ の導入に使用した前報》 の JIS-y 割れ栻験データには，HAZ の $H_{\max }$ の実測値

*原稿受付 昭和59年 2 月28日（全国大会諭文発表譚满）

**名篦具新日本製鉄 Honorary Member, Nippon Steel Corporation
がないので，その化学成分之冷却時临から百合阔ら2) 推定式で計算した $H_{\max }$ 值を利用した。百合阙らの式

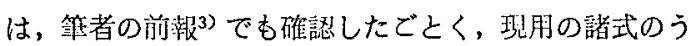
ち最も高精度な式の一つであり次式で与えられる。

$$
\begin{aligned}
& H_{\max }(\mathrm{Hv} 10)=406 \mathrm{C}+164 \mathrm{C}_{\mathrm{e}_{\mathrm{q}}} \mathrm{I}+183 \\
& -\left(369 \mathrm{C}-149 \mathrm{C}_{\mathbf{e}_{\mathbf{q}}} \mathrm{I}+100\right) \arctan X \text {, } \\
& X \equiv \frac{Y-2.822 \mathrm{C}_{\mathrm{e}_{\mathrm{q}}} \mathrm{II}+0.262}{0.526-0.195 \mathrm{C}_{\mathrm{eq}_{\mathrm{q}}} \mathrm{II}} \text {, } \\
& Y \equiv \log t_{8} / 5, t_{8 / 5} \text { (s) } \equiv \text { cooling time from } \\
& 800^{\circ} \text { to } 500 \mathrm{C} \\
& \mathrm{C}_{\mathrm{eq}_{\mathrm{q}}} \mathrm{I} \equiv \mathrm{C}+\frac{\mathrm{Si}}{24}+\frac{\mathrm{Mn}}{6}+\frac{\mathrm{Cu}}{15}+\frac{\mathrm{Ni}}{40}+\frac{\mathrm{Cr}}{6} \\
& +\frac{\mathrm{Mo}}{4}+10 \mathrm{~B}+\frac{\mathrm{Nb}+\mathrm{V}}{5} \\
& \mathrm{C}_{\mathrm{eq}_{\mathrm{q}}} \mathrm{II} \equiv \mathrm{C}-\frac{\mathrm{Si}}{30}+\frac{\mathrm{Mn}}{5}+\frac{\mathrm{Cu}}{5}+\frac{\mathrm{Ni}}{20}+\frac{\mathrm{Cr}}{4} \\
& +\frac{\mathrm{Mo}}{6}+10 \mathrm{~B} \text {. }
\end{aligned}
$$

ここで $\mathrm{C}_{\mathrm{e}_{\mathbf{q}}} \mathrm{I}$ は $t_{8 / 5}$ が大きくマルテンサイト0\%の $H_{\max }$ に関し， $\mathrm{C}_{\mathbf{e}_{\mathbf{q}}}$ II は急冷で $100 \%$ マルテンサイト組 織中にフェライトが出現し始める場合のかたさに関する 炭素当量である.

著者は前報引で百合阙式の近似式として次の NSC-S 式を導入し， $H_{\max }$ が $P_{\mathrm{cm}}, \mathrm{C} \%$ 及び $t_{\mathrm{g} / 5}$ の 3 因子で精 度良く推定できるととを示した。すなわち,NSC-S 式： 


$$
\begin{gathered}
H_{\max }(\mathrm{Hv} 10)=\left(187+64 \mathrm{C}+485 P_{\mathrm{cm}}\right) \\
-\left(97+680 \mathrm{C}-441 P_{\mathrm{cm}}\right) \arctan X \\
X \equiv \frac{Y+\left(0.501+7.90 \mathrm{C}-11.01 P_{\mathrm{cm}}\right)}{\left(0.543+0.55 \mathrm{C}-0.76 P_{\mathrm{cm}}\right)} \\
Y \equiv \log t_{8 / 5}, \quad\left(t_{8} / \mathrm{sin} s\right) . \\
P_{\mathrm{cm}}(\%) \equiv \mathrm{C}+\frac{\mathrm{Si}}{30}+\frac{\mathrm{Mn}+\mathrm{Cu}+\mathrm{Cr}}{20}+\frac{\mathrm{Ni}}{60} \\
+\frac{\mathrm{Mo}}{15}+\frac{\mathrm{V}}{10}+5 \mathrm{~B}
\end{gathered}
$$

この式の妥当性を示す一例として，Fig. 1 は伊藤・別 所の報告4)の付表のIIW $H_{\max }$ 試験（ビード溶接）結果 を,筆者が $P_{\mathrm{cm}}$ に対してプロットしたもので著しくばら ついている. 板厚 $25 \sim 50 \mathrm{~mm}$, 入熱 $17 \mathrm{~kJ} / \mathrm{cm}$ ，予熱な し $\left(22 \mathrm{C}\right.$ )のビード溶接なので $t_{8} / \mathrm{s}=6.5 \mathrm{~s}$ (共通)，供試 鋼はHT 50 HT 100 級高張力錀 101 種で，C％=0.07

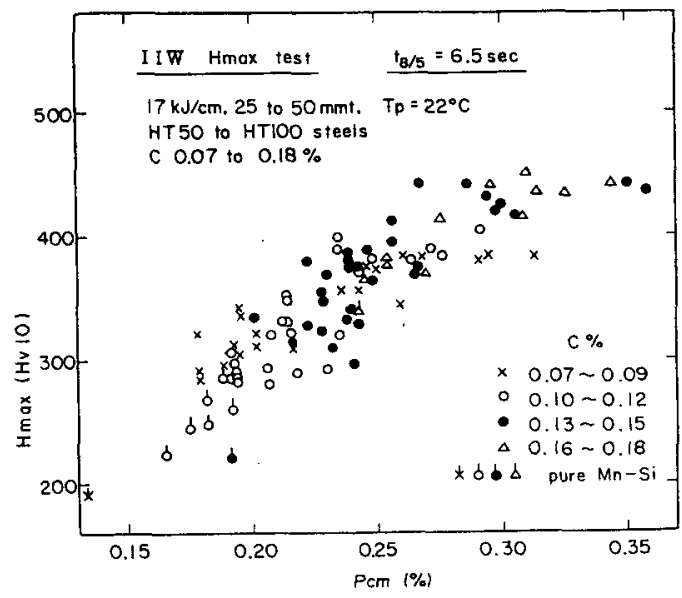

Fig. 1 Relationship between $H_{\max }$ and $P_{\mathrm{cm}}$ for IIW $H_{\max }$ test of HT50 to HT100 steels, 25 to $50 \mathrm{~mm}$ thick, $17 \mathrm{~kJ} / \mathrm{cm}$ and without preheating. Effect of $\mathrm{C} \%$ level. (compiled from Ito-Bessyo test data).

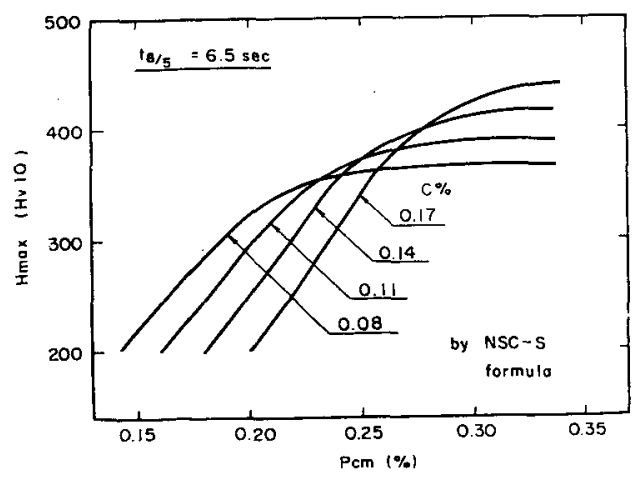

Fig. $2 H \max$ versus $P_{\mathrm{cm}}$ and $\mathrm{C} \%$ for $t_{8} / \mathrm{s}=6.5 \mathrm{~s}$, predicted by NSC-S formula.

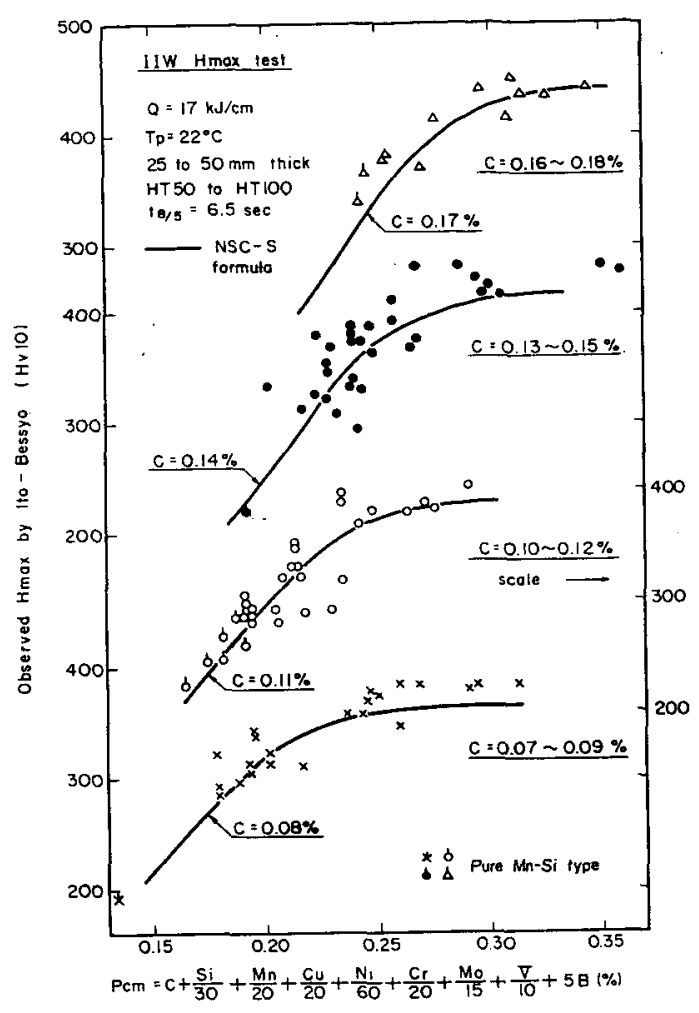

Fig. 3 Comparison of $\mathrm{Hmax}$ values observed by Ito-Bessyo with predicted values calculated by NSC-S $\left(\boldsymbol{P}_{\mathbf{c m}}\right)$ formula (simplified from NSC-Y formula).

〜0.18\%で，図は C\% 別記記を買にしてプロットし た.

式(2)の著者の式では，C％別に Fig. 2 の曲線獭がえら れる. $H_{\max }$ は $340 \sim 420 \mathrm{Hv} 10$ 程度までは, $P_{\mathrm{cm}}$ の增 加に比例して増大するが，やがてある飽利値（C\% で決 まる）澾して頭打ちになる，予測值を哭測佔と此較す ると Fig. 3 のように，C％ レベル別にすれば阿者はよ く一致していると言えよう。

\section{3. 限界水素濃度}

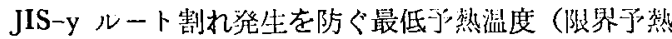
温度）の場合に，割れ発生点におりる時刻 $t_{100}$ （凝固時 より $100^{\circ}$ Cに冷却するまでの時阙）での限界水渠浱度 $H_{c}$ の值は，水䋜が一様に搪散すると仮定して，前赫 $\left(P_{H A}\right)^{1)}$ に示した力法で計算できる. $H_{c}$ は各板厚 (拘州 度 $R_{F^{\prime} y}$ ) 每水,

$\log H_{c}=a-b P_{\mathrm{cm}},\left(a, b\right.$ は $R_{F y}$ で決まる常数)

であらわされ, $\log H_{c}$ と $P_{\mathrm{cm}}$ は Fig. 4 の例（板厚 30〜 $32 \mathrm{~mm}$ ）に示すように，相関はかなり良好である。 


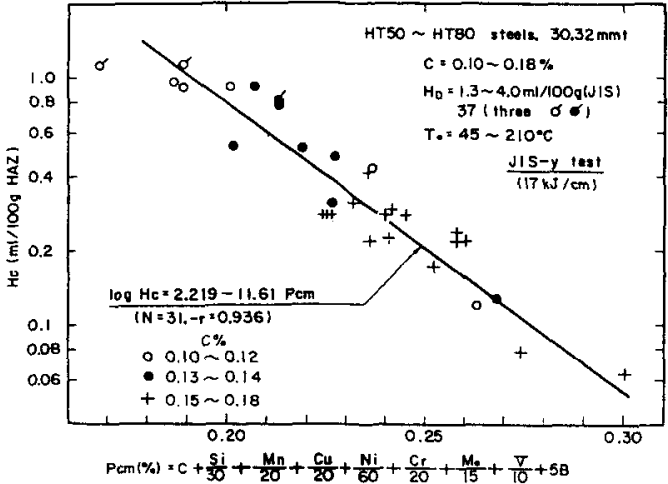

Fig. 4 Correlation between critical hydrogen concentration $H_{c}$ and carbon equivalent $P_{\mathrm{cm}}$ for $30 \mathrm{~mm}$ thick HT50 to HT80 steels (JIS-y) test).

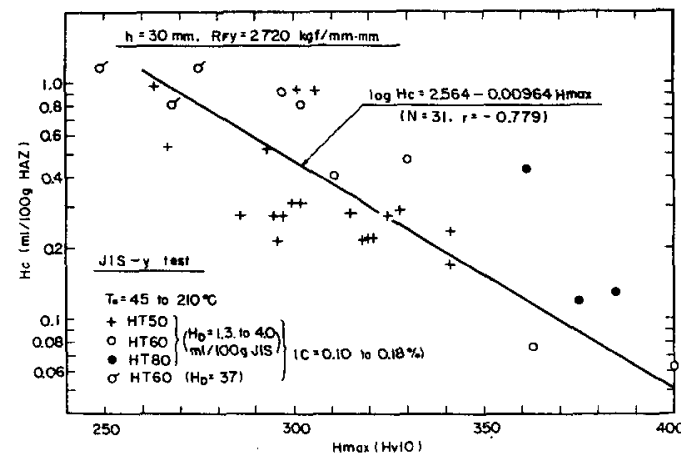

Fig. 5 Relation between critical hydrogen concentration $H_{c}$ and maximum hardness in the HAZ for $30 \mathrm{~mm}$ thick HT50 to HT80 steels (JIS-y test, $17 \mathrm{~kJ} / \mathrm{cm}, R_{F y} 2720 \mathrm{kgf}$ ) $\mathrm{mm} \cdot \mathrm{mm})$.

これに反し, $\log H_{c}$ と $H_{\max }$ の関係は, Fig. 5 に示す ように相関不良である。板厚 $50 \mathrm{~mm}, 25 \mathrm{~mm}$ 及び 20 $\mathrm{mm}$ の場合む図は省略するが，相関不良である，従来， 低温割れ性の尺度としては， $H_{\max }$ はバラッキが著しく て利用できないとみなされていた通りである。しかし後 で $P_{H A}$ 解析によってわかるように， $H_{\max }$ は $\mathrm{C} \%$ と併 せてはじめて低温割れの尺度となりうるもので，次にそ のととを示す。

\section{4. 限界取高かたさの $\boldsymbol{P}_{H A}$ による推定}

\section{$4.1 P_{B A}$ 式}

前報”によると, JIS-y 割机発生の陵界冷却時間（と

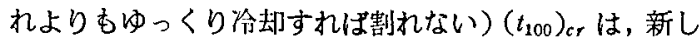
い割れ指数 $P_{H A}$ を用いて次式で与えられる。

$$
\left(t_{100}\right)_{c r}(s)=\mathrm{fn}\left(\boldsymbol{P}_{\boldsymbol{B A}}\right)
$$

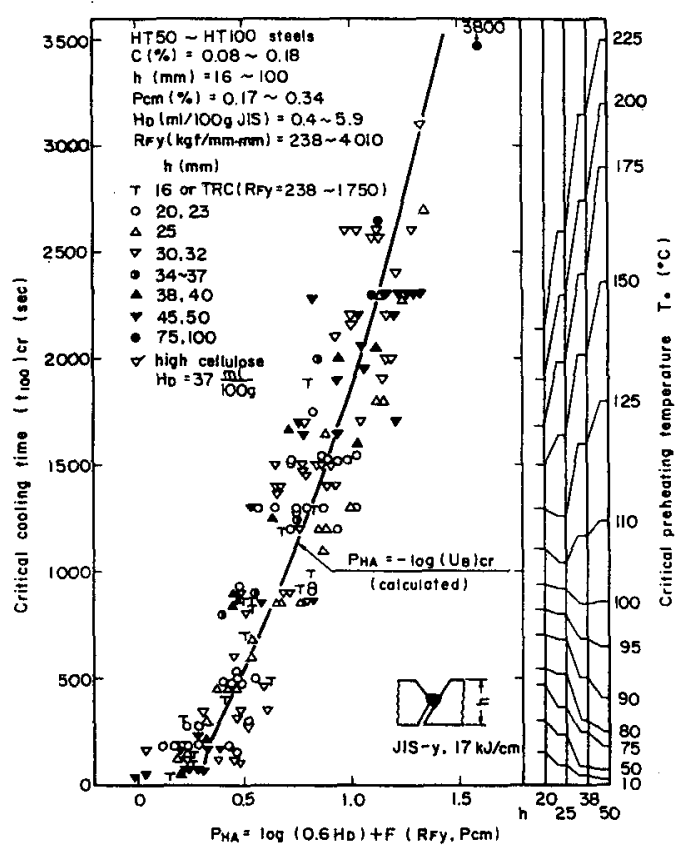

Fig. 6 Relationship between critical cooling time $\left(t_{100}\right)_{C r}$ and cracking parameter $P_{H A}$ for JIS-y (oblique-y) test of HT50 to HT100 steels (by revised $P_{H A}$ formula).

この関数は水素㹡散で決まるもので, Fig. 6 中の曲線で 与えられる1). 著者の割れ指数 $P_{\boldsymbol{H A}}$ は次式で与えられ， $P_{B A}$ がわかる之限界冷却時間 $\left(t_{100}\right)_{c r}$ の值がわかり，板 厚と入熱に応じて限界予熱温度が決められる。

$$
\begin{aligned}
& P_{B \boldsymbol{A}} \equiv-\log \left(U_{B}\right)_{c r} \equiv-\log \left(H_{C} / H_{F}\right)_{c r}, \\
& P_{H A} \equiv F+\log \left(0.6 H_{D}\right) \text { ，（低水絭系） } \\
& \equiv F+\log \left(0.24 H_{D}\right) \text {, } \\
& \text { （高セルローズ系） } \\
& F \equiv-\log H_{C}=-a+b P_{\mathrm{cm}} \text {, } \\
& \left(a, b \text { は } R_{F y} \text { の関数 }\right)
\end{aligned}
$$

for $R_{F y}<1000 \mathrm{kgf} / \mathrm{mm} \cdot \mathrm{mm}$

$$
\begin{gathered}
F=\left(6.32+2.60 \times 10^{-3} R_{F y}\right) P_{\mathrm{cm}}-0.1 \\
\times 10^{-3} R_{F y}-1.92,
\end{gathered}
$$

for $1000 \leqq R_{F y}<2090$

$$
\begin{gathered}
F=\left(7.71+1.19 \times 10^{-3} R_{F y}\right) P_{\mathbf{c m}}-0.1 \\
\times 10^{-3} R_{F y}-1.93,
\end{gathered}
$$

for $2090 \leqq R_{F y}<2720$

$$
\begin{aligned}
F=(4.55+2.67 & \left.\times 10^{-3} R_{F y}\right) P_{\mathrm{cm}}-0.268 \\
& \times 10^{-3} R_{F y}-1.58,
\end{aligned}
$$

for $2720 \leqq R_{F y}$

$$
F=11.9 P_{\mathrm{cm}}+0.089 \times 10^{-3} R_{F y}-2.55
$$

ただし $H_{D}(\mathrm{ml} / 100 \mathrm{~g})$ : 溶着金属の搪散性水䋕量 (JIS Z 3113) 
$H_{F}(\mathrm{ml} / 100 \mathrm{~g}):$ fused metal の拡散性水素量 (JISZ 3113)

$R_{F y}(\mathrm{kgf} / \mathrm{mm} \cdot \mathrm{mm})$ : 等価拘束度 ${ }^{2}$ グルーブ形 状とビード位置の偏心率で決まるが，JIS-y 試験片では 従来の拘束度 $R_{F}$ 亿等しい.

\section{$4.2 \boldsymbol{H}_{\sigma}$ と $\left(\boldsymbol{H}_{\max }\right)_{c r}$ の関係}

JIS-y 試験では式 (5)，(6)，(7) により， $H_{C}$ と $\left(H_{\max }\right)_{c r}$ の関係が次の手順で求められる。

一定板愿 $\left(R_{F y}=\right.$ const $) に$ 対して,

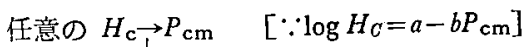

$$
\begin{aligned}
& \text { 任意の } H_{D} \stackrel{\downarrow}{\rightarrow}\left(U_{B}\right)_{c r}\left[\because H_{C}=0.6 H_{D} \cdot\left(U_{B}\right)_{c r}\right]
\end{aligned}
$$

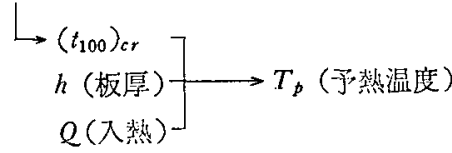

$$
\begin{aligned}
& \left.\begin{array}{r}
\left.\left(T_{p}, h, Q\right) \rightarrow t_{8 / 5} *\right) \\
P_{\mathrm{cm}}, C
\end{array}\right]-(\mathrm{NSC}-\mathrm{S} \text { 式 }) \rightarrow\left(H_{\max }\right)_{c r}
\end{aligned}
$$

Fig. 7 出板厚 $h=30$ と $32 \mathrm{~mm}\left(R_{F y}=2720 \mathrm{kgf} / \mathrm{mm} \cdot \mathrm{mm}\right)$ $(Q=17 \mathrm{~kJ} / \mathrm{cm})$ の場合に上述の手順で計算した $H_{C}$ と $\left(H_{\max }\right)_{c r}$ の関係である. $H_{C}$ の減少に伴って $P_{\mathrm{cm}}$ が增 加し， $\left(H_{\max }\right)_{c r}$ が增大する. $H_{D}=2$ と4 で少し異なる がその平均は鎖線で与えられる。. C $\%=0.10,0.15$, 0.18 で $H_{C}$ に大差があり， $H_{\max }<380 \mathrm{Hv} 10$ の䈌困で は同一 $H_{\max }$ なら C\% が低い结ど限界水素濃度 $H_{C}$ が 高い，すなわちルート割れが起こりにくいととを示して いる.

Fig. 7 の推定結果を実测值と比較すると Fig. 8 がえら れる. 実測値は $H_{D}=1.3 \sim 4.0$ の筙围内にあるから, 推 定伹 Fig. 7 の平均曲線 $\left(H_{D}=2\right.$ と 4$)$ を用いればよいで あろう. C\% $\%=0.10 \sim 0.12$ の测定値 (白丸印) は， $P_{B A}$

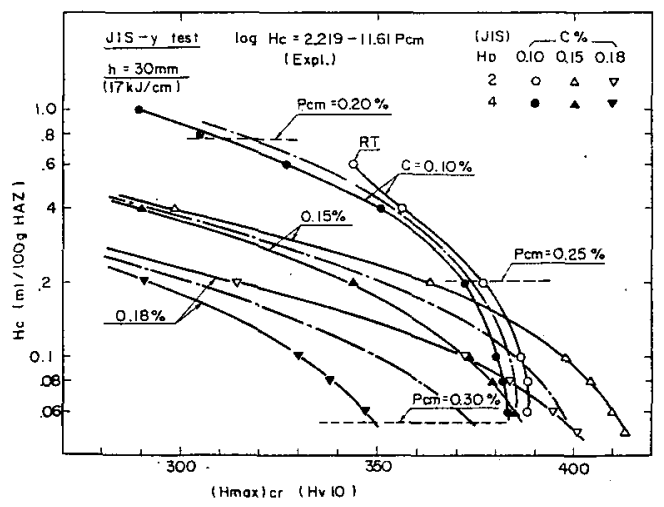

Fig. 7 Rèlationship between $H_{c}$ and $\left(H_{\max }\right)_{c r}$ for JIS-y test, as predicted by $P_{B A^{-}}$-analysis for $30 \mathrm{~mm}$ thickness.

* $t_{8 / 5}$ の算定には百合的らの訢算式（溶接治金研究委 只会資料 WM784-80（1980-8月）により，グルーブがある場合の值を用いだ

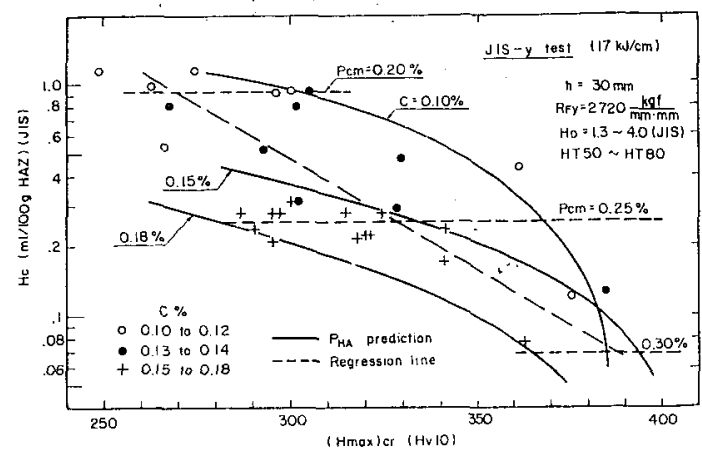

Fig. 8 Comparison between observed and $P_{H_{4}}$ predicted values of the critical hydrogen concentration $H_{c}$ for the JIS-y test, as regards the effects of carbon content $\mathrm{C}$ and $P \mathrm{~cm}$ for $30 \mathrm{~mm}$ thick HT50 to HT80 steels.

推定の $\mathrm{C}=0.10 \%$ 曲線上に活果乘って抢り,さらにC $\%=0.13 \sim 0.14 \%$ および $C \%=0.15 \sim 0.18 \%$ の測定值 も，それらに相当する $P_{H A}$ 推定曲線とかなりよく合致 している.

Fig. 7 で明膫なように, $\log H_{C} \sim\left(H_{\max }\right)_{c r}$ の関係は銅 の C\% によりかなり相達するから，C\% を無視して比 较すると Fig. 5 亿示すように相関不良任見えるのは当 然である.とれに反して, $\log H_{C} \sim P_{\mathrm{cm}}$ の関係 (Fig. 4) には $\mathrm{C} \%$ の影響が認められない事実は，低温割れ性の 尺度としての $P_{\mathrm{cm}}$ の利点を示すもので, $\left(H_{\max }\right)_{c r}$ よ り格段淃る。

\section{3 予熱不要の $\left(\boldsymbol{H}_{\max }\right)_{c r}$ の推定}

$P_{\text {HA }}$ の式(7)で与えられる $\log H_{C}=a-b P_{\mathrm{cm}}$ 中の常 数 $a, b$ を用いると，予熱不要の場合 $\left(T_{p}=20^{\circ} \mathrm{C}\right)$ のルー 卜割れ発生の限界かたさ $\left(H_{\max }\right)_{c r}$ が次の手順で求めら れる.

表 $1 k P_{H A}$ 式に用いた板厚每の $a, b$ の値を示す. $Q=17 \mathrm{~kJ} / \mathrm{cm}$ で予熱しはい場合の $t_{100}$ 上 $t_{8 / 5}$ 及び $P_{H A}$ の值む示されている.拘束度 $R_{F}, \leqq 1000 \mathrm{kgf} / \mathrm{mm} \cdot \mathrm{mm} の$ 場合は，甚になった伊藤・別所の実験值》が，板厚 20〜 $38 \mathrm{~mm}$ (最多 $25 \mathrm{~mm}$ ) の, 㑡面スリット付き試験片で低 拘束度を実現した場合なので，表 1 で冷却時間に影響す る板厚としては代表值 $25 \mathrm{~mm}$ を採用した。 $\left(H_{\max }\right)_{c r}$ は次の手順で求められる。

$$
\begin{aligned}
& h \text { (板厚) } \longrightarrow R_{F y} \longrightarrow(a, b \text { 値 }) \\
& \text { (h, } Q=17 \mathrm{~kJ} / \mathrm{cm}, \text { JIS-y, } \dot{T}_{p}=20^{\circ} \mathrm{C} \text { ) } \\
& \left.\rightarrow\left(t_{100}\right)_{c r}\right)=\mathrm{fn}(h) \\
& \left(R_{F y}, P_{H A}, H_{D} \text {, 式 (7) } \rightarrow P_{\mathrm{cm}}\right] \\
& \left(C \%, t_{8} / 5\right) \\
& \longrightarrow(\mathrm{NSC}-\mathrm{S} \text {. 式 }) \longrightarrow\left(H_{\max }\right)_{c r}
\end{aligned}
$$


表 1 予熱不要の限界 $H_{\max }$ 推定用数値表 (JIS-y 試験, $17 \mathrm{~kJ} / \mathrm{cm}$ )

\begin{tabular}{|c|c|c|c|c|c|c|c|c|c|}
\hline$R_{F^{\prime} y}(\mathrm{kgf} / \mathrm{mm} \cdot \mathrm{mm})$ & 3390 & 2720 & 2440 & 2090 & 1000 & 750 & 500 & 250 & $(0)$ \\
\hline$h(\mathrm{~mm})$ & 50 & 30 & 25 & 20 & \multicolumn{5}{|c|}{ ( $h \div 25 \mathrm{~mm}$ のスリッr付き) (外括) } \\
\hline$a$ & 2.248 & 2. 312 & 2.229 & 2. 135 & 2. 030 & 1.993 & 1.968 & 1.943 & 1. 918 \\
\hline$b$ & 11.90 & 11.90 & 11.06 & 10.13 & 8.90 & 8.27 & 7.62 & 6.97 & 6.32 \\
\hline$\left(t_{100}\right)_{c r}(\mathrm{~s})$ & 50 & 80 & 120 & 180 & 120 & 120 & 120 & 120 & 120 \\
\hline$P_{H A}$ & 0.303 & 0.305 & 0.312 & 0.333 & 0.312 & 0.312 & 0.312 & 0.312 & 0.312 \\
\hline$t_{8 / j}(\mathrm{~s})$ & 5.6 & 5.8 & 5.9 & 6.2 & 5.9 & 5.9 & 5.9 & 5.9 & 5.9 \\
\hline
\end{tabular}

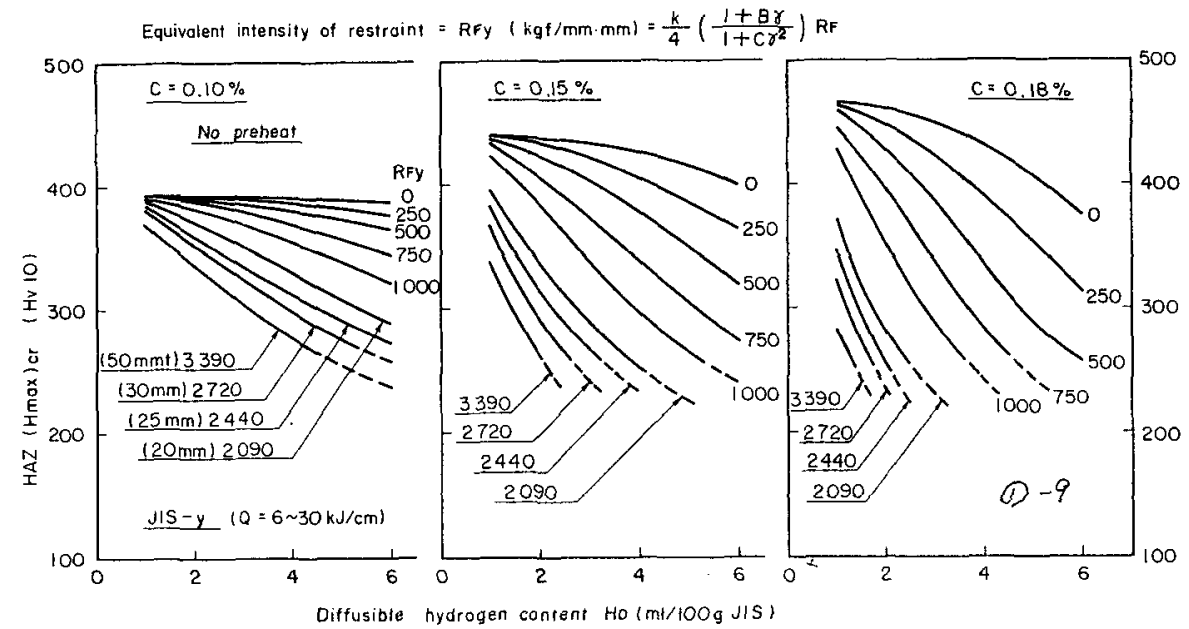

Fig. 9 Critical values of $\mathrm{HAZ} H_{\max }$ to prevent root cracking in one pass weld $\mathrm{HAZ}$ as related to diffusible hydrogen content $H_{D}$ and equivalent intensity of restraint $R_{\text {Fy }}$ for JIS-y test without preheating $(Q=6 \sim 30 \mathrm{~kJ} / \mathrm{cm}, \mathrm{HT} 50$ to HT100 steels).
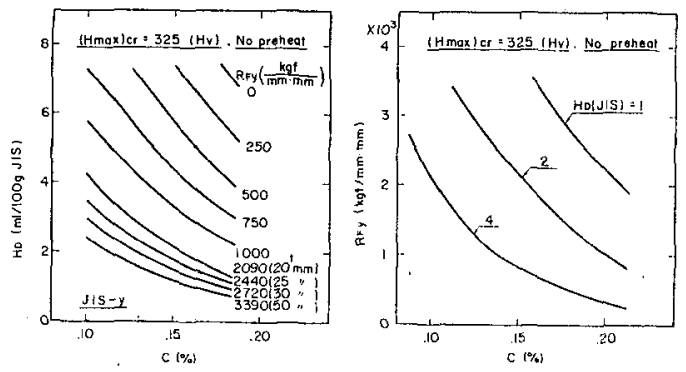

Fig. 10 Relationship between $\mathrm{C} \%, H_{D}$ and $R_{F}$, for the critical value of $\left(H_{\max }\right)_{c r}=325$ in the JIS-y test without preheating $(Q=6 \sim$ $30 \mathrm{~kJ} / \mathrm{cm}$ ).

計算結果の一例を Fig. 9 亿示す. $\mathrm{C}=0.10,0.15$ お よび0. $18 \%$ 場合に応じて， $\left(H_{\max }\right)_{c r}$ を $H_{D}$ と $R_{F y}$ 別 に求めた． $R_{F y}$ が著しく小さいときは， $H_{D}$ の影響が少 なくなり $\left(H_{\max }\right)_{c r}$ は $\mathrm{C} \%$ て決まる館和かたさに近つ き， $\mathrm{C} \%$ が大きいほど限界加たさが大きい. しかし拘束 度がきびしい場合とくに $R_{F y}>2000 \mathrm{kgf} / \mathrm{mm} \cdot \mathrm{mm}$ では, G\%が低いほど逆に限界かたさが大きくなる。

最近の海洋棈造物の溶接施工では，溶接部が何処でも

\section{$H_{\text {max }} \leqq 325 \mathrm{Hv}$}

などと規定される場合が多い．Fig. 9 よりとの条件に対 する $\mathrm{C} \%, H_{D}$ 及び $R_{F}$ ， の組合わせを Fig. 10 亿示す. 同一拘束度に対しては，C\% が低いほど $H_{D}$ の值が大き くて良いことが示されている。

\section{4 予熱 $100^{\circ} \mathrm{G}$ の $\left(\boldsymbol{H}_{\max }\right)_{c r}$ の推定}

前節之同様汇予熱 $100 \mathrm{C}$ C 場合の限界かたさを計算し て Fig. 11 亿示す. また $\left(H_{\max }\right)_{c r}=325$ の条件を Fig. 12 に示す．限界かたさ，制れ発生時点 $\left(t_{100}\right)$ での残留水素 濃度が予熱なしの場合にくらべて約半隇（Q=17 kJ/cm の場合)するから，それだけ $H_{D}$ の許容量が増加する。 乙れは Fig. 12 に示した実線（予熱 $100{ }^{\circ} \mathrm{C}$ ) 乙破線（予熱 なし）の比較からよく分る。

$$
\text { 5. 応用 }
$$

本報告で導かれた JIS-y 試験のルート割れ発生の限 界かたさを他の実験結果と比較してみよう。

英国溶研で行われた原沢・Hart の実験5)では，H ス リット形自拘束割れ試験片を用いて，突合せ X形グルー ブのルート割れ試験を板厚 $25 \mathrm{~mm}$ の 3 種の C-Mn 蜍 板に対して，予熱なしで溶接入熱を変えて実施し，拘束 

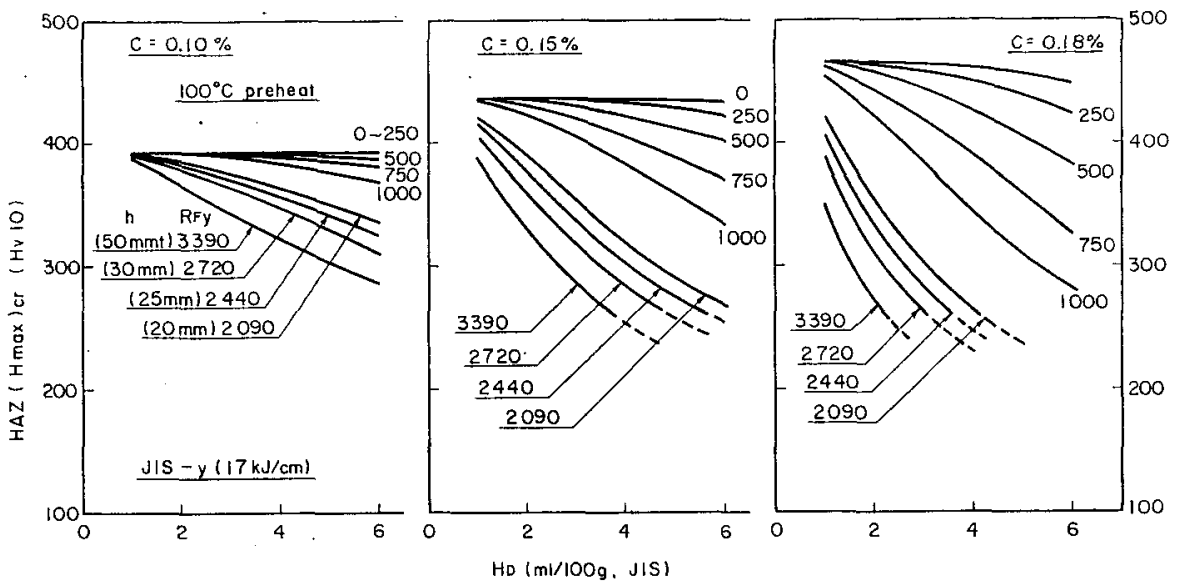

Fig. 11 Critical values of $\mathrm{HAZ} H_{\max }$ to prevent root cracking in one pass weld HAZ in JIS-y test under $100^{\circ} \mathrm{C}$ preheating $(Q=17 \mathrm{~kJ} / \mathrm{cm}, \mathrm{HT} 50$ to $\mathrm{HT} 100$ steels).
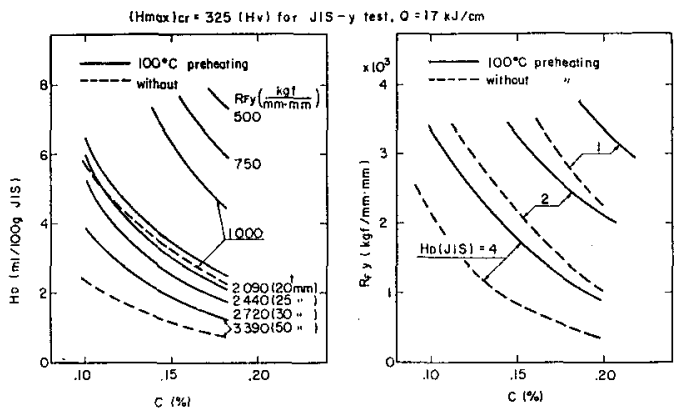

Fig. 12 Relationship between $\mathrm{C} \%, H_{D}$ and $R_{F y}$ for $\left(H_{\max }\right)_{c r}=325(\mathrm{Hv})$ in the JIS-y test, $Q=17 \mathrm{~kJ} / \mathrm{cm}$, with $100^{\circ} \mathrm{C}$ preheating (and without).

度, 水素量, 及び $H_{\max }$ が割れ発生に及济す影響を調べ て，Fig. 13 と Fig. 14 をえた. 彼等のX形グルーブの拘 束度 $\mathrm{K}$ と著者の等価拘束度 $R_{\mathbb{F} y}$ の関係は前報》により

$$
R_{F_{y}}=(3.5 / 4) \mathrm{K}
$$

で与えられるからたとえば $K=2500(\mathrm{~N} / \mathrm{mm} \cdot \mathrm{mm})$ は $R_{F y}=223(\mathrm{kgf} / \mathrm{mm} \cdot \mathrm{mm})$ になる。

彼等の試験片に対しては，予熱しない場合の $t_{100}(s)$ 之入熱 $Q$ の関係は近似的に次式で与えられる $(25 \mathrm{~mm}$ 厚, $20^{\circ} \mathrm{C}$ ).

$$
Q(\mathrm{~kJ} / \mathrm{cm})=1.410 \sqrt{t_{100}} \exp \left(0.0003617 t_{100}\right)
$$

予熱なしの場合の 4.3 節の手順を用いて, $P_{H A}$ 解析を 利用して限界かたさを求めると，Fig. 13，14 中の破線が えられる。

Fig. $13, \mathrm{C}=0.16 \%$ と $\mathrm{C}=0.20 \%$ で $H_{D}=1.5 \mathrm{ml} /$ $100 \mathrm{~g}$ (JIS)

の場合は，推定と実測結果はかなり良く一致す る.
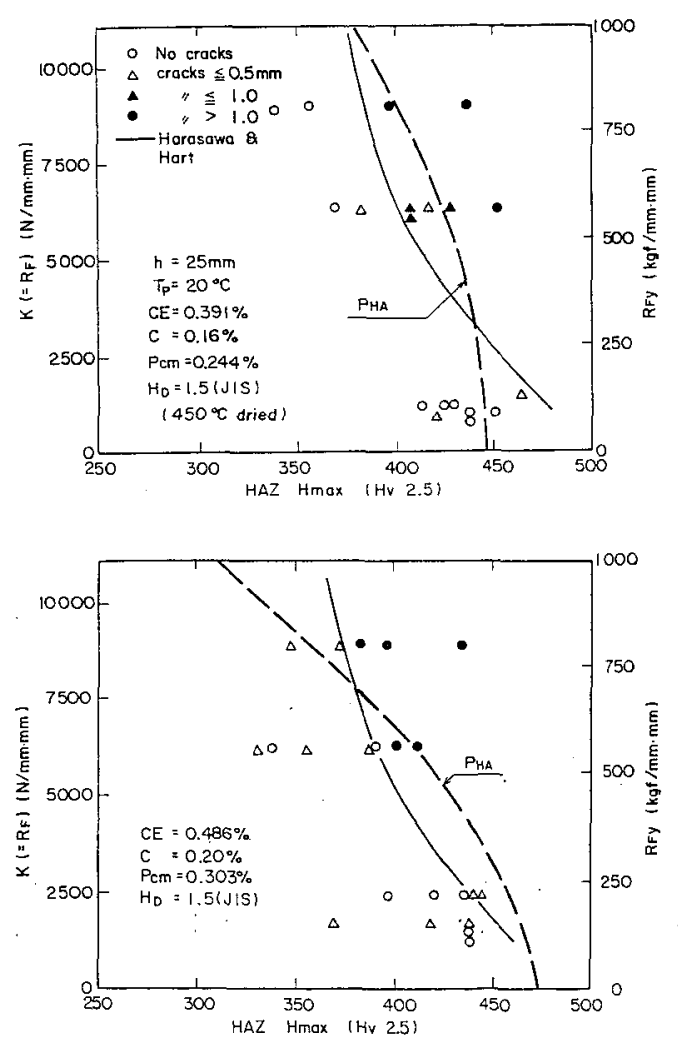

Fig. 13 Critical HAZ $H_{\max }$ for steels $0.39 \mathrm{CE}$ and $0.49 \mathrm{CE}$ without preheating (X-groove test by Harasawa and Hart).

Fig. 14, $C=0.25 \%$ で $H_{D}=1.5$ の場合は，ほぼ一 致する.

$C=0.16 \%$ て $H_{D}=6.6$ の場合は, 定性的に一 致する. 

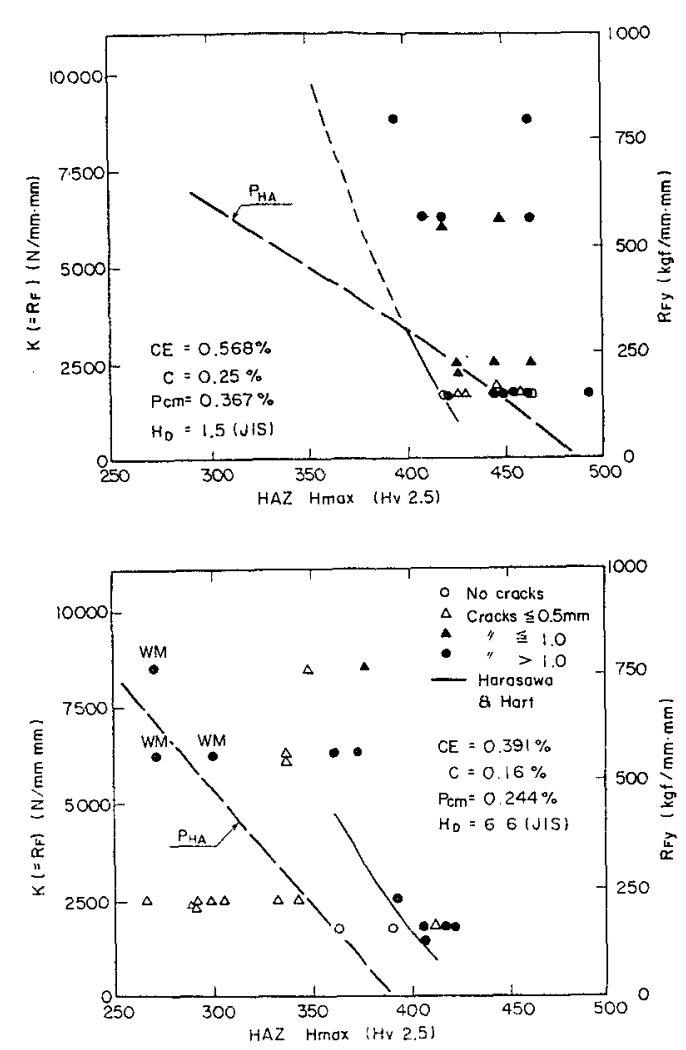

Fig. 14 Critical HAZ $H_{\max }$ for steels $0.57 \mathrm{CE}$ and $0.39 \mathrm{CE}$ without preheating ( $\mathrm{X}$-groove test by Harasawa and Hart).

ただし，Fig. 14 で $C=0.25 \%$ 鋼は $P_{\mathrm{cm}}$ の適用筙囲 (C $\leqq 0.22 \%)$ 外である。 また Fig. 14 の $H_{D}=6.6$ (JIS) は， $P_{\boldsymbol{B A}}$ 式が，主として $H_{D}=1.3 \sim 4.0$ の範围の割れ データを基に作られているので, $H_{D}=6.6$ の場合には 誤差を生ずるのか西知れない，しかし Fig.13 よりみて $\left(H_{\max }\right)_{c r}$ の $P_{B A}$ 推定值は, 原沢らの実験データとか なり良く一致すると思われる。

なお $P_{\text {HA }}$ 解析では，一定入熱 $(Q=17 \mathrm{~kJ} / \mathrm{cm}) の \mathrm{JIS}-\mathrm{y}$ 試験で，予熱温度と化学成分を变えて $H_{\max }$ を変化さ せているのに対して，欧州では予熱なしで入熱量と化
学成分を変えて $H_{\max }$ を変化させたデータが多いので, 今後亡あ日欧のデータの比較は，むっ上多くの実験デ一 タについて確認の必要がある。

\section{6. 結 論}

以上, 新しい劃れ指数 $P_{H A}$ の導入に利用した JIS-y 割れ試験デー夕を対象に、ルート割れ発生の限界 $H_{\text {max }}$ を計算した，低温割れ性の評価には $P_{\mathrm{cm}}$ は単独で有効 であるが， $H_{\max }$ 単独では評価困酄（相関不良）ほとと が判明し，C\% と組合わせて初めて役立つてとがわかっ た.同一の $H_{\max }$ の $\mathrm{HAZ}$ では, $\mathrm{C} \%$ が低いほよ゙水素 割れに強いととがわかった。

さらに，予熱不要の場合と， $100^{\circ} \mathrm{C}$ 予熱が必要な場合 の限界 $H_{\max }$ 值を， C \%，抎散性水素量 $H_{D}$ 及び拘束 度 $R_{F y}$ 別に求めた。 $H_{\max }=325 \mathrm{Hv}$ を限界かたさとする $\mathrm{C} \% H_{D}$ 及び $R_{F y}$ の組合せ条件をあ示した。

なお本報の限界 $H_{\max }$ の推定值は，英国の実験デ一 タとよく一致することを示した。

さらに HAZ の $H_{\max }$ 值を, $\mathrm{C} \%, P_{\mathrm{cm}} \%$ 及び $t_{8 / 5}$ の 3 因子で精度よく推定できる簡便式（NSC-S 式）を を示した。

謝辞 本研究に際し新日鉄第二技研の百合岡博士のご 協力に感謝する.

\section{参 考 文 献}

1）蛉木，奥村：“新しい割れ指数 $P_{H A}$ による命間割れの解析”， 本学会諭交集 2 (1984) No. 1，17-23，及び Trans. JWS, 14 (1983), No. 1, 40-52.

2）百合岡，奥村，萌菲：“銅溶接部の椧却特性と硬化性の推定”，溶 治委 WM-784-80，1980-8月，1-27.

3) 鈴木: “Carbon Equivalent and Maximum Hardness," 溶治委 WM-931-83，1983-5月一25日，1-24. 及び Trans. JWS, 15 (1984) No.1, 25-33.

4) 伊藤, 别所: “Cracking Parameter of High Strength Steels related to Heat-Affected-Zone Cracking," IIW Doc. IX-576-68, 1968.

5) 原沢, Hart: “A Preliminary Evaluation of the Effect of Restraint on HAZ Cold Cracking of Butt Welds in Three C-Mn Steels," TWI Rep. 40/1977/M, June 1977, 1-36. 